\title{
炎症マウスに括ける造血幹細胞
}

\section{青木 功・外山圭助*}

Hematopoietic stem cells of mice in inflammation

Isao Aoki - Keisuke Toyama*

・炎症や感染症などに挴いて貧血を合併することは周知 の事実であるが，その貧血の機序の詳細は解明されて拉 らず, 特に炎症時の造血幹細胞動態の研究は少ない.今 回は炎症実験モデルとしてテレピン油膿瘍マウスを作成 し，その骨髄および脾造血幹細胞の測定を行ったので報 告する.

\section{方 法}

実験動物は C $57 \mathrm{BL} / 6$ マウス (雌性, 8〜19週齢), 1 群 6 〜 10 匹を用いた。炎症処置として, テレピン油 (turpentine oil) を大腿部に筋注 $(7.5 \mathrm{ml} / \mathrm{kg})$ 乙, 1 週 ごとに末梢血白血球数, $\mathrm{Ht}$ 值, 骨髄ならびに脾造血幹 細胞を测定した. 対照として同量の生食水をマウス大腿 部に投与した。

造血幹細胞の測定は Iscove らの方法に準じ，すべて メチルセルロース法 (FCS $30 \%$ 含 $\alpha$-medium) にて施 行した. 骨髄および脾 CFU-C は L cell conditioned me$\operatorname{dium} 10 \%$ 添加にて 7 日間培養, CFU-E はエリトロポ エチン (erythropoietin, Ep, sheep step III, Connaught 社, Canada) 0.5 単位添加にて 2 日後, BFU-E は Ep 2.0単位添加して10日後, CFU-mix は Ep 2.0単位とマ ウス脾細胞培養上清を添加して10日間培養後に測定を行 った.

\section{結果と考察}

テレピン油投与 $2 \sim 5$ 日後, 局所の腫脹出現, $7 \sim 10$ 日目ごろより大腿部に径 8〜10 $\mathrm{mm}$ のほぼ球形を呈する 腫瘍が形成された。末梢血白血球数は対照マウス 5,500 $\pm 300\left(/ \mathrm{mm}^{3}\right)$ [平均土標準誤差]に比し，テレピン油投 与にて 1 週目 $9,800 \pm 900,2$ 週目 $10,500 \pm 700$ と増加を 示し, $3 \sim 5$ 週のやや軽減するも増加は持続した(図 1 ). それに対し一大腿骨の骨髄 CFU-C は $1 \sim 2$ 週と軽度増 加を示した（図 1). 一方, 脾 CFU-C はテレピン油投 与後 1 ～ 2 週で対照マウスに比し著増を示した（図 2 ）.

* Department of Internal Medicine, School of Medicine, Keio University 慶応義塾大学医学部 内科学教室
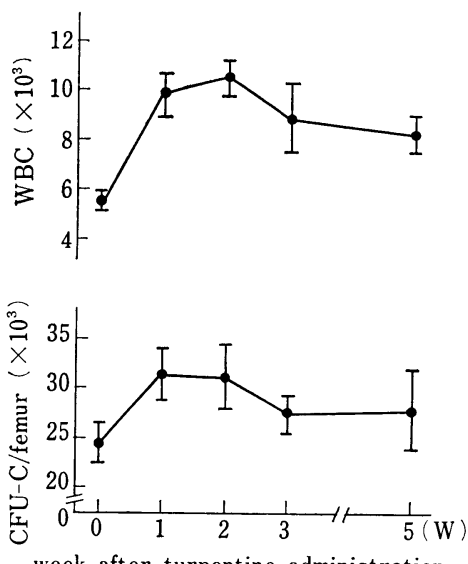

図 1 WBC and CFU-C (/femur) of turpentine treated mice

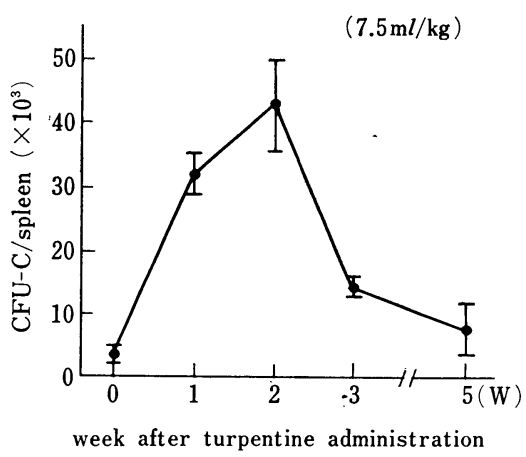

図 2 CFU-C of spleen in turpentine treated mice

したがって, テレピン油投与による末梢血白血球数の増 加は, 前駆細胞である CFU-C の骨髄および脾での増加 に起因するものと考学られた。 末梢血 $\mathrm{Ht}$ 值は対照マウ

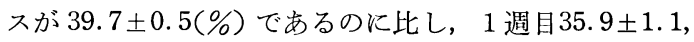
2 週目 $33.7 \pm 2.0,3$ 週目 $36.5 \pm 1.1$ と低下し， 5 週目に 回復するも，なお低值を示していた（図 3).

赤血球系前駆細胞 CFU-E は一大腿骨にて，1週目よ り著減を示し，2～ 5 週まで減少を示した〔対照: 53.0 $\pm 6.7\left(\times 10^{3}\right) ; 1$ 週目: $20.8 \pm 1.1 ; 2$ 週目 : $27.2 \pm 9.0$; 3 週目: $29.8 \pm 7.1 ; 5$ 週目: 43.9土19.5]（図4）.

一方, 脾 CFU-E は 1 〜 週目で増加を示したが, 一 大腿骨の造血は全身の造血の拈よそ $8 \%$ と考えられてい 


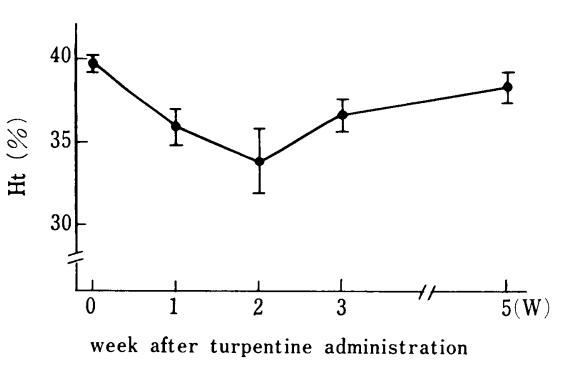

图 3 hematocrits of turpentine treated mice

るので3)，一大腿骨の CFU-E 量より全身骨髄の CFU-E 量を換算して減少量を算出すると, 脾での増加を差し引 いても全身の CFU-E は 1 〜 週にかけてすべて対照マ ウスより減少することが確認された。

CFU-E より 1 段階幼若な CFU-E についても測定を 行ったが, BFU-E 同様骨髄では著減を示し, 脾で増加 を示した. CFU-E も全身骨髄に換算して計算すると， 骨髄での減少のほうが脾での増加を上まわって拈り，全 身の BFU-E 量はテレピン油投与により $1 \sim 5$ 週におい て減少を示した。

また CFU-E, BFU-E よりさらに幼若で, 赤血球系, 白血球系, 栓球系の 3 系統いずれにも分化しらる能力を もつ多能性幹細胞の一種と考えられる CFU-mix につい て測定を行った。一大腿骨の CFU-mix は, 1 週目10土 9 (\% of control) と著減を示し， 2 週目 $52 \pm 18(\%), 3$ 週目 $119 \pm 18(\%), 5$ 週目 $82 \pm 31(\%)$ と， 2 週目以降 徐々に正常化した，骨髄で CFU-mix が減少したのは, 技そらく局所へ白血球を動員する目的で CFU-mix から

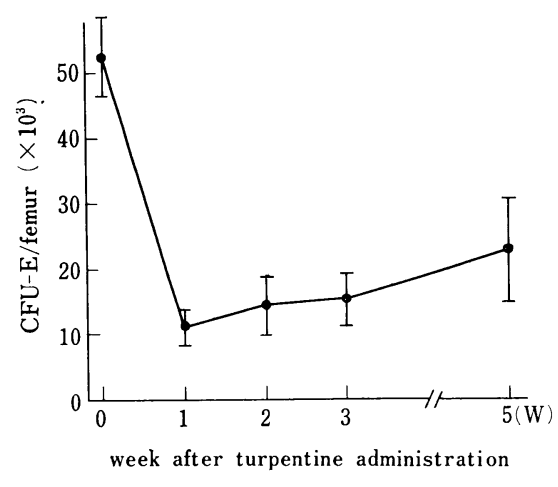

図 4 CFU-E (/femur) of turpentine treated mice

CFU-Cへ急速に分化が進んだことによると考えられる。 また，その結果として赤血球系の BFU-E, CFU-E の減 少, さらに貧血へとつながったものと推察される.

\section{文 献}

1) Iscove, N.N., Sieber, F., Winterhalter, K.H.: Erythroid colony formation in cultures of mouse and human bone marrow; analysis of the requirement for erythropoietin by gel filtration affinity chromatography on agarose-concanavalin-A. J. Cell. Physiol. 83: 309-320, 1974.

2) 外山圭助, 青木 功: 赤血球系細胞の分化. 細胞 14: 508-513, 1982.

3) Vácha, J., Holá, J., Dungel, J., Znojil, V.: The distribution of erythropoiesis over the various anatomical regions of the mice. Exp. Hematol. 10: 768-773, 1982. 